\title{
外来入侵种紫茎泽兰研究进展与展望
}

\author{
鲁 萍 桑卫国 * 马克平 \\ (中国科学院植物研究所植被数量生态学重点实验室, 北京 100093)
}

\begin{abstract}
摘 要 紫茎泽兰 (Eupatorium adenophorum) 是 20 世纪 40 年代经中缅边境传入我国的一种外来入侵种, 原产于中美 洲的墨西哥和哥斯达黎加, 现已在我国南方和西南地区广泛分布, 并且其蔓延速度极快, 引起了社会各界的广泛关 注。近年来, 随着研究的不断深入和拓展, 新的研究成果不断涌现, 使紫茎泽兰成功入侵的机理性问题不断被揭示 出来。该文简要介绍了目前我国关于紫茎泽兰研究的几个热点问题, 这些问题主要围绕着紫茎泽兰的分布和预 测、入侵扩散机制以及防除方法 3 个方面展开。其中以紫茎泽兰作为典型外来入侵种来研究其入侵扩散机制的工 作最多。该文就目前的研究进展做一综述, 并提出今后的研究建议。
\end{abstract}

关键词 紫茎泽兰 分布预测 入侵扩散机制 防除

\section{PROGRESS AND PROSPECTS IN RESEARCH OF AN EXOTIC INVASIVE SPECIES, EUPATORIUM ADENOPHORUM}

\author{
LU Ping SANG Wei-Guo* and MA Ke-Ping \\ ( Laboratory of Quantitative Vegetation Ecology, Institute of Botany, Chinese Academy of Sciences, Beijing 100093, China)
}

\begin{abstract}
Eupatorium adenophorum, native to Mexico and Costa Rica of Central America, is a worldwide noxious invasive weed. It occurs throughout many terrestrial areas of the world and is especially rampant in Southeast Asia, Hawaii (U.S. ), New Zealand, Australia, and the Pacific Islands. Since its invasion to China from the boundaries of Vietnam and Burma, the speed of its spread has been faster than anticipated, particularly in the southern and southwestern parts of the country. Presently, E. adenophorum can be found in Chongqing, Yunnan, Sichuan, Guizhou, Tibet, Guangxi, Taiwan and Hubei Provinces. A rough estimate of the annual spreading rate of $E$. adenophorum is about $10-60 \mathrm{~km}$ from south to north and from west to east in China. It is considered a threat to local economy and biodiversity. As a result, an increasing number of Chinese scientists have become interested in studying this species and much progress in understanding the biology and ecology of this species has been made to date. In particular, much is known about the underlying mechanisms of its invasion biology .

This paper reviews some of the hot research topics of this invasive species in China, including its distribution, predicting its potential distribution, the mechanisms underlying its invasion and spread, and methods for control and elimination. The distribution of this invasive plant in China has been mapped and its potential distribution has been predicted using a computer model based on climatic factors.

Among current research efforts, understanding the mechanisms underlying its invasion and spread is one of the hottest topics. Recent research also has studied the patterns of genetic variation within populations of the invasive weed, novel biochemical mechanisms of interspecies interactions, biological characteristics of the invasive species that explain its highly successful spread, e.g., small seed size, persistent soil seed bank, high offspring production, potential long-distance dispersal of propagules, vegetative reproduction, relatively high $\mathrm{CO}_{2}$ fixation capacity, shade tolerance, high adaptive ability, and tight link of life-history traits with climatic rhythm.
\end{abstract}

Although much progress in understanding the biology and ecology of this species has been achieved, there have been no dramatic breakthroughs on how to control $E$. adenophorum so far. At present, control methods of E. adenophorum are divided into three general categories: manual, chemical and biological control. Bio- 
logical control is considered the most promising sustainable control strategy for this weed. Several natural enemies and pathogens have been reported that might be able to control the reproduction of this weed, such as Procecidochares utilǐs, Cercospora eupatorii and Alternaria alternata.

The current status of research on the invasive species, E. adenophorum, was reviewed in this paper. Five areas of future research have been proposed: 1) modeling long-distance seed dispersal; 2) allelopathic mechanisms of invasion; 3) ecophysiological adaptations of the invasive species; 4) breeding system of the invasive species; and 5) effective biological control of the invasive species, especially the potential role of genetically engineered fungi.

Key words Eupatorium adenophorum, Distribution, Invasion mechanisms, Biological control

紫茎泽兰 (Eupatorium adenophorum) 是我国外来 入侵物种中危害最为严重的植物之一, 属于菊科泽 兰属, 原产于中美洲的墨西哥和哥斯达黎加。作为 一种有害的外来物种现已在夏威夷、澳大利亚、新西 兰、泰国等地爆发式繁衍, 广泛分布在世界热带、亚 热带 30 多个国家和地区。此物种大约于 20 世纪 40 年代从中缅边境通过自然扩散传入我国云南省, 约 经半个世纪的扩散, 现已在我国的云南、贵州、四川、 广西、西藏、台湾等 4 省 2 区广泛分布和危害(强胜, 1998; 李振宇和谢炎, 2002), 并仍以每年大约 $60 \mathrm{~km}$ 的速度, 随西南风向东和北传播扩散 (向业勋, 1991)。在重庆和湖北的三峡地区亦发现紫茎泽兰, 并采集到标本 (段慧, 2003)。

作为一种入侵性很强的外来物种, 关于紫茎泽 兰的研究无论在国外 (Bess \& Haramoto, 1959; Dodd, 1961; Auld, 1969a, 1969b, 1971; Auld \& Martin, 1975; Arunachalam et al., 1999; Papes \& Peterson, 2003 ), 还是在国内 (刘伦辉等, 1985, 1989; 赵国晶和 马云萍, 1989; 强胜, 1998; 周俗和谢永良, 1999; 宋启 示等, 2000; 强胜, 2004）都已经开展了很多。目前国 内的研究热点主要集中在 3 个方面: 1 ) 分布范围及 可能扩散的区域;2)紫茎泽兰侵入扩张的机理;3)防 除方法。本文就邓外来入侵种的研究现状做一总结 和展望, 以期对我国正在进行和将要进行的有关研 究有所禆益。

\section{1 分布范围及可能扩散的区域}

\section{1 紫茎泽兰在中国的分布}

在云南省, 据调查, 紫茎泽兰在 10 个地、州的 98 个县、市都有发生, 面积达 24.77 万 $\mathrm{km}^{2}$, 其中以西南 部和南部地区发生量最大(赵国晶和马云萍, 1989)。 在四川省, 2002 年对全省紫茎泽兰的分布进行了调 查, 发现自 1978 年在凉山州盐源县树河乡发现紫茎
泽兰以来, 已经在凉山州、攀枝花市、乐山市、宜宾 市、雅安市、甘孜州 6 个市 (州) 共 34 个县 (区) 、400 多个乡镇有紫茎泽兰分布, 面积达 86.478 万 $\mathrm{hm}^{2}$, 成 灾面积达 82.277 万 $\mathrm{hm}^{2}$ 。其中凉山州和攀枝花市为 全省的重灾区, 占全省紫茎泽兰分布面积的 $99.15 \%$ (周俗等, 2004)。在贵州省, 1991 年, 已分布到黔西 南、黔南、安顺、六盘水等 4 个地、州(市) 的兴义、兴 仁等 14 个县, 其中侵入面积较大的有兴义、册享、望 谟、安龙等 4 个县的南部地区。其分布范围已超越 $26^{\circ} \mathrm{N}$, 接近 $107^{\circ} \mathrm{E}$, 并有逐渐向贵州省东北方向发展 蔓延的趋势(向业勋, 1991)。在西藏自治区, 在聂拉 木县也有发现(陈开基, 1989)。在广西壮族自治区, 20 世纪自 70 年代传入以来, 到目前为止, 最东达到 横县, 最北分布在乐业和南丹, 在百色地区的田林、 西林、隆林三地入侵最为严重, 另外在南宁、靖西、平 果、天蛾也有发生 ${ }^{1)}$ 。紫茎泽兰在台湾省也有分布 (李振宇和解炎, 2002)。在重庆和湖北的三峡地区 发现紫茎泽兰, 并采集到其标本, 这是目前我国分布 纬度最北的记录(段惠,2003)。总之, 目前紫茎泽兰 在我国的大致分布范围如下: 南起中缅、中越边境地 区, 北抵沪定-胖为-宜宾-重庆一线, 西起贡山-冕宁石棉, 东到横县-南宁-南丹-贵阳-重庆一线。危害最 严重的地区位于 $102^{\circ} \mathrm{E}$ 左右, 包括: 云南省的临沧、 思茅、昆明, 广西省的百色, 贵州省的黔西南、四川的 攀枝花和凉山(卢志军和马克平, 2004)。

2003 年 $3 \sim 6$ 月, 李振宇等通过资料收集、标本 研究和野外调查, 在紫茎泽兰的重灾区云南、四川、 贵州、广西等地作较详细的调查, 并收集紫茎泽兰在 中国 6 个省区的县(市)级分布资料, 通过整理和分 析, 在原有的紫茎泽兰分布图 (李振宇和解炎, 2002) 的基础上, 又进行了补充, 重新绘制了分布图 (图 $1)^{2)}$ 。

\section{2 预测其可能扩散的区域}




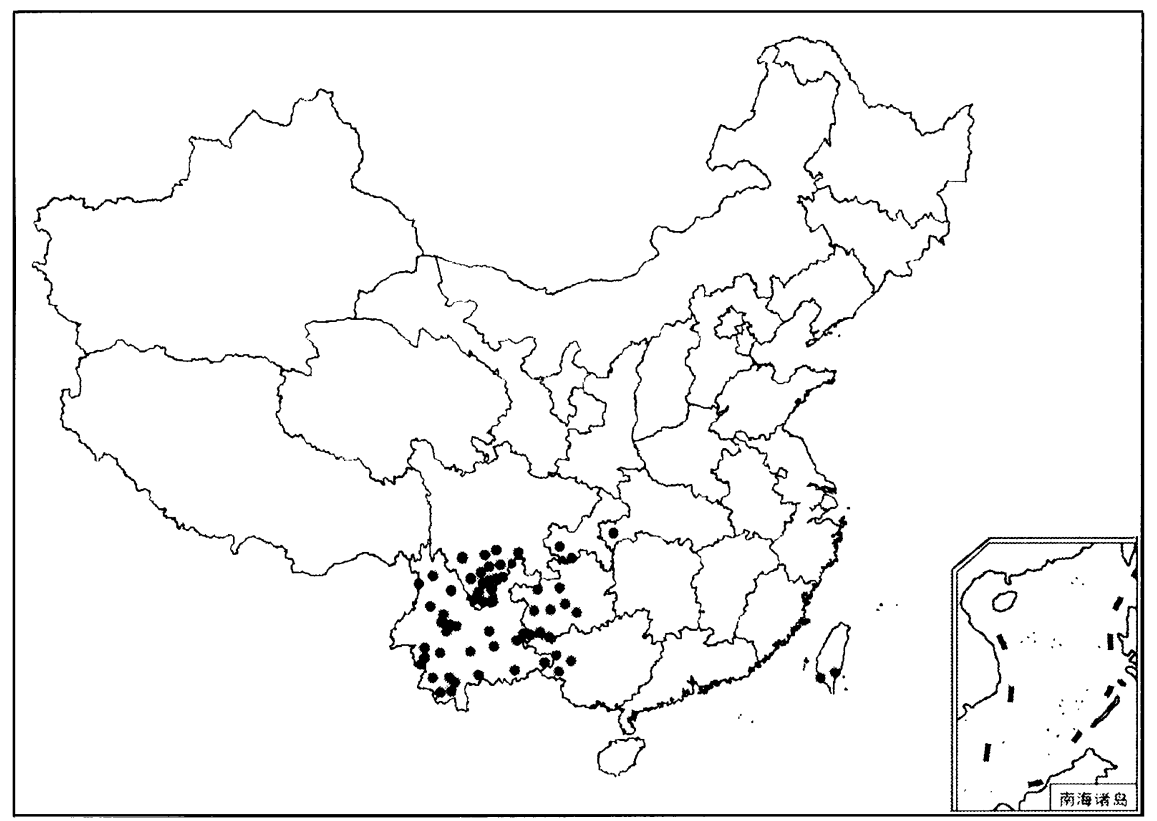

图 1 紫茎泽兰在中国的分布示意图

Fig. 1 Distribution of Eupatorium adenophorum in China

据调查数据测算, 8 年间紫茎泽兰向北纬推进 了两度半, 直线距离约 $280 \mathrm{~km}$, 平均每年在凉山州 境内向北传播 $35 \mathrm{~km}$ (周俗和谢永良, 1999)。由此可 见, 紫茎泽兰扩展速度相当惊人, 因而, 对其蔓延趋 势做出预测, 已成为迫切需要解决的问题。

依据危害地区的生境条件分析, 可以看出它对 土壤类别并无选择, 但水热条件和光照确是影响它 能否生长与危害的限制因子(刘伦辉等, 1985)。赵 国晶和马云萍(1989)等通过调查也发现温度和湿度 是影响紫茎泽兰发生的主要气候因子, 并提出紫茎 泽兰可以在年平均温度大于 $10^{\circ} \mathrm{C}$ 、年平均相对湿度 高于 $68 \%$ 、绝对最低温不低于 $-11.5{ }^{\circ} \mathrm{C}$ 、最高气温 $35{ }^{\circ} \mathrm{C}$ 以下、最冷月平均温度大于 $6{ }^{\circ} \mathrm{C}$ 的气候条件下 适宜生长, 并做出预测, 认为紫茎泽兰可能入侵长江 以南各省区。

最近, 已经有学者应用生态位模拟的方法, 通过 收集其原产地墨西哥和中国的气象资料, 来预测紫 茎泽兰可能入侵的范围。预测的范围包括该植物在 中国境内已分布的省份及未来在华中、华东易受入 侵的区域。通过模型预测, 目前紫茎泽兰分布的 6 个省区当中的 4 个省份 (云南、贵州、四川、广西)与 模型所预测的分布区十分吻合, 而西藏自治区则包 括在模型所预测分布区的边缘地带。预测的潜在分 布区包括: 甘肃、宁夏、陕西、山西、河南和湖北 5 省 1 区, 而且模型还预测了和目前分布区不相连的两
个潜在分布区, 分别在我国的东北和东南, 这些潜在 分布区包括东北的黑龙江省、辽宁省和东南的福建 和浙江两省 (Papes \& Peterson, 2003)。

卢志军和马克平 (2004)通过调查其在我国的分 布状况、比较其在原产地 (墨西哥和哥斯达黎加)与 我国分布区的地形因素和气候条件, 也对其潜在分 布区进行了推测: 紫茎泽兰在不断地向东向北推进, 但最终分布格局还将以云贵高原为主体, 随着分布 区扩大到云贵高原以外,它的扩展速度、危害程度都 将逐渐降低。

\section{2 紫茎泽兰侵入扩张的机理研究}

紫茎泽兰作为一个成功的入侵种, 兼备了许多 入侵杂草所具有的显著特征, 对其入侵机制和扩散 机制的研究有助于其它有害入侵植物的研究, 丰富 和发展入侵生态学理论, 推动我国外来入侵植物学 研究的进步。

\section{1 紫茎泽兰侵入扩张的分子机理研究}

生物入侵为我们提供了很多快速适应与进化的 经典模型。紫茎泽兰分布范围较广, 生境条件多样, 因此, 从分子生态学的角度对不同侵入地区及不同 生态环境中的紫茎泽兰进行遗传多样性分析, 探索 其遗传变异规律, 开展紫茎泽兰分子生态适应机制 的研究, 对于解释紫茎泽兰的入侵机制有积极意义。 紫茎泽兰作为一种入侵性极强的外来物种, 目前其 
入侵原因尚不明了, 从遗传学角度揭示其根源已经 成为生物学界关注的热点 (强胜, 2004)。

强胜(2004)利用 AFLP 技术, 对 24 个地区的紫 茎泽兰种群的基因组 DNA 多态性进行了检测, 并通 过 UPGMA 聚类分析对结果进行了分析, 结果表明: 1)紫茎泽兰遗传多样性丰富, 具有广泛的生态适应 性;2)紫茎泽兰入侵时间长的云南省遗传多样性较 高, 入侵时间短的新入侵地区的遗传多样性则相对 较低; 3) 风媒和水媒可能是紫茎泽兰传播的途径, 因 为可以在样点间观察到明显的地缘性亲缘关系。

\section{2 紫茎泽兰侵入扩张的“新武器”一化感作用}

近年来, Callaway 和 Aschehoud (2000)提出了“新 武器” 的假说, 认为外来入侵种的入侵成功主要归因 于其改变了入侵地的植物及微生物群落原有的种间 关系, 引入了新的相互作用机制, 这种改变最初主要 是通过生物化学物质加以实现。并通过实验证明, 外来入侵种铺散矢车菊( Centaurea diffusa) 所具有的 化感作用, 在入侵地对本地种发挥了比在原产地对 原共生种更大的作用, 是其在入侵地成功入侵和扩 散的强大武器。

作为一种世界性的恶性杂草, 紫茎泽兰已经被 许多研究证明具有很强的化感作用 (Tripathi et al., 1981; Angiras et al., 1988, 1989; 赵国晶和马云萍, 1989; 和爱军和刘伦辉, 1990; Baruah et al., 1994; 宋 启示等, 2000; 于兴军等, 2004)。紫茎泽兰的水浸提 液可以对黑麦草 (Lolium perenne)、白三叶 (Trifolium repens) 等植物的种子发芽和胚根与胚芽伸长产生抑 制作用。紫茎泽兰不同部位的化感作用也不同, 叶 的抑制作用远大于根茎 (和爱军和刘伦辉, 1990); 最 近于兴军等(2004) 也通过实验发现, 对于紫茎泽兰 的入侵力来说, 地上部分的化学作用比地下部分具 有更大的贡献。不同提取方法也会影响紫茎泽兰的 化感作用, 赵国晶和马云萍(1989)研究表明: 紫茎泽 兰叶水提取液的化感作用 $>$ 叶乙醚提取液的化感作 用; 而紫茎泽兰根的化感作用则相反, 即根乙醚提取 液的化感作用 $>$ 根水提取液的化感作用。于兴军等 (2004)通过对比紫茎泽兰入侵的不同生境发现, 不 同生境下紫茎泽兰茎和根的水浸提液的化感作用存 在差异, 即公路边 > 落叶阔叶林 > 常绿阔叶林, 并通 过关联分析显示出不同生境条件下的化感作用与本 地植物的相对多度存在显著的相关关系, 证明不同 生境下化感作用的差异是造成紫茎泽兰入侵效果的 原因之一。

对紫茎泽兰化学成分的研究可以揭示它与其它
植物和动物相互作用的基础, 阐明化感作用的化学 机制, 也是目前的研究热点之一。在国外, Bohlmann 和 Rajindex(1981) 从紫茎泽兰中分离得到 4 种化合 物和 6 种倍半萜烯; Bordoloi 等( 1985) 从紫茎泽兰中 分离得到 5 种具有昆虫拒食活性的倍半萜烯类化合 物; Baruah 等( 1994) 也分离鉴定了紫茎泽兰的化感 物质为倍半萜烯化合物。在我国, 许多学者开展了 紫茎泽兰化感物质的研究。许云龙等 (1988) 从紫茎 泽兰中分离得到 $\beta$-谷甾醇, 豆甾醇, 蒲公英甾醇、棕 㭣酸酯及蒲公英甾醇乙酸酯等化合物; 李蓉涛等 (1997) 从紫茎泽兰中分离得到 8 种化合物; 丁智慧 等(1999)从紫茎泽兰的花中分离到 12 个化合物, 其 中紫茎泽兰内酯为一新的杜松烯类倍半萜内酯化合 物, 另一种从紫茎泽兰中提取到的克拉维醇, 是首次 从泽兰属植物中分离得到, 活性篮选显示这种化合 物对小菜粉蝶幼虫 (Pieris rapae) 具有一定的拒食活 性; 宋启示等(2000)通过研究其地上部分的石油醚、 乙酪和水提取物对豇豆 (Pisum sativum) 的种子萌发 和幼苗生长的化感作用发现, 它的化感物质主要集 中于石油醚提取物及石油醚提取物吸附于活性炭后 的甲酪洗脱物中。从石油醚提取物分离出的第二、 第三和第四组分为主要的活性成分, 且经鉴定, 化感 活性强的石油醚第二组分为 9-酮-泽兰酮。提出了 紫茎泽兰地上部分挥发性化感物质的释放以及地上 部分和调落物中的水溶性化感物质的淋溶等植物化 感途径。

\section{3 紫茎泽兰有利于入侵的生物学特性}

目前, 入侵生物学的很多工作都集中在确定外 来入侵种的关键生物学特性及判断和预测一个物种 是否成为入侵种上, 而这些工作往往是以研究成功 入侵种所具有的生物学特性为基础的 (Bazzaz, 1986;

Newsome \& Noble, 1986; Noble, 1989; Hobbs \& Humphries, 1995; Rejmánek \& Richardson, 1996)。

紫茎泽兰的种子非常有利于扩散, 且具有适应 长距离传播的机制。紫茎泽兰种子数量多, 每株可 结种子 $3 \sim 4.5$ 万粒, 多的可达 10 万粒 (刘伦辉等, 1989); 种子很轻, 种子千粒重只有 $0.040 \sim 0.045 \mathrm{~g}$ (周俗和谢永良, 1999), 种子顶端具冠毛, 可通过瘦 果与冠毛形成的“风伞”随风飘移扩散, 种子在冠毛 的辅助下, 借助风力、水力、人畜车辆流动进行广泛 传播; 种子成熟期正遇上春季西南季风, 风速大 $\left((2.5 \sim 3.5) \mathrm{m} \cdot \mathrm{s}^{-1}\right.$ ), 利于种子传播扩散 ( 向业勋, 1991)。所以, 紫茎泽兰每年产生的大量种子广泛分 布在入侵地的不同生境中, 在土壤中保持数量巨大 
的土壤种子库 (沈有信和刘文耀, 2004)。

紫茎泽兰具有长久性土壤种子库 (沈有信和刘 文耀, 2004), 所以它的种子能在土壤中等待萌发时 机, 在新的种子季节到来时仍然保持活力。有长久 性土壤种子库的植物在适应多变的生境和不良的生 长条件方面具有优越性, 即使植物的种子在某个年 份因为自然灾害或人为因素而减产甚至无种子产生 时, 植物种群也不会受到灭绝的威胁 (Thompson \& Grime, 1979; Thompson, 2000), 而这对于紫茎泽兰来 说, 无疑为它未来的入侵提供了源源不断的后备力 量,即使短时间被消灭,一旦条件适宜，土壤种子库 中的种子又会快速建立新的种群。

紫茎泽兰的繁殖方式多种, 除种子之外, 还可以 用根、茎进行无性繁殖, 茎和分枝有须状气生根, 具 有萌发根芽的能力, 入土便能繁殖成新植株( 向业 勋, 1991)。C Cook (1985) 发现, 水生植物的分布区在 原产地与入侵地存在很大差别, 水生植物的分布在 入侵地所受到的阻力要远远小于原产地, 无性繁殖 能力很可能是最主要的原因。而紫茎泽兰脱离了原 产地的天敌, 在新的入侵地入侵成功并迅速扩散, 很 可能与无性繁殖能力有关。另外, 紫茎泽兰含有的 化学物质使动物拒食, 使其自身的种群不断增长, 也 是其入侵成功的原因之一。

紫茎泽兰是一种无融合生殖的三倍体 $(n=$ 17)，不经授粉和受精即可形成无配子种子（Baker， 1965; Auld, 1970; Tendani \& Steven, 2004)。最近, 研 究发现紫茎泽兰的花粉粒具有二型性, 小型花粉粒 大小为 $15 \sim 25 \mu \mathrm{m}$, 大型花粉粒大小为 $25 \sim 35 \mu \mathrm{m} 。$ 因为紫茎泽兰为三倍体植株, 推测花粉粒二型性是 由花粉粒的倍性引起的, 小型花粉粒为单倍体, 大型 花粉粒为二倍体 ${ }^{1}$ 。

紫茎泽兰的生物学特征与其入侵地气候变化节 律的吻合也是其入侵成功的重要因素。在四川攀枝 花市和凉山州, 紫茎泽兰在 1 2 月现蕾, $2 \sim 3$ 月开 花, 4 5 月种子成熟, 此时正是该地区的大风季节, 而且河谷风总是顺谷从南向北刮, 加之往来汽车流 量大, 人畜流动频繁更有助于其传播 (周俗和谢永 良, 1999)。在云南,紫茎泽兰孕蕾时间多从 11 月下 旬开始, 12 月下旬现蕾, 翌年 2 月中下旬始花, 新枝 萌发从连续降雨的 5 月开始, 5 9 月为生长旺期, 其中以高温高湿的 7、8 月为最快, 11 月花芽分化, 株高增加下降(刘伦辉等, 1989)。雨季正值紫茎泽
兰种子成熟后期, 为其萌发和幼苗生长提供了极为 有利的条件。

紫茎泽兰具有广泛的适应性和抗逆能力, 无论 在向阳开阔的自然草场、公路两旁还是在荫蔽的桐 林亦能成片生长, 甚至在石缝、㾉薄的土壤中也能生 长发育( 向业勋, 1991)。在云南省, 紫茎泽兰随温 度、湿度的变化垂直分布在海拔 165 2915 m 之间, 高差达 $2750 \mathrm{~m}$, 包括了热带、南亚热带、中、北亚热 带、暖温带和温带 6 个气候带 (赵国晶和马云萍, 1989)。

紫茎泽兰具有很强的光合能力, 其最大光合速 率为 $23 \mu \mathrm{mol} \mathrm{CO}_{2} \cdot \mathrm{m}^{-2} \cdot \mathrm{s}^{-1}$ 左右 (王俊峰等, 2004)。 紫茎泽兰的光饱和点比较高, 接近阳性植物; 紫茎 泽兰对光照的适应范围较宽, 光补偿点低, 仅为 13 $\mu \mathrm{mol} \cdot \mathrm{m}^{-2} \cdot \mathrm{s}^{-1}$ 左右, 而 $\mathrm{CO}_{2}$ 补偿点为 $80 \mu \mathrm{mol} \cdot \mathrm{mol}^{-1}$ 左右, 具有阳性偏阴的生态习性(刘文耀等, 1988), 适应大幅度的光环境很可能是其入侵成功的重要原 因之一。另外, 王俊峰和冯玉龙 (2004) 通过实验也 发现, 紫茎泽兰对光环境较强的适应能力可能是紫 茎泽兰的入侵性强于兰花菊三七( Gynura sp.) 的重 要原因。紫茎泽兰通过叶片自遮荫来适应强光, 高 度自遮荫可以阻止其它植物在其冠内生长, 而其自 身的耐荫能力却很强, 在相当于林下光强的弱光环 境中仍能生长, 并具有较强的光合能力 (王俊峰等, 2004)。刘文耀等(1988) 发现从夏季到秋季, 紫茎泽 兰叶片的日平均光合速率不仅没有减少, 而且略有 增加, 说明紫茎泽兰一直处于旺盛的生长状态, 而在 这期间, 正是牧草及其它一些植物幼苗、幼树生长能 力衰退的时期。紫茎泽兰所具有的这些光合特性都 是其成功入侵的生理基础。

\section{3 紫茎泽兰的防除}

\section{1 紫茎泽兰的人工防除}

将紫茎泽兰在秋冬季进行挖除, 晒干烧毁,而后 立即种上适应性强、繁殖快的牧草和树种, 如象草 ( Pennisetum purpureum)、狗芽根 (Cynodon dactylon)、 刚莠竹 (Microstegium ciliatum)、白三叶以及云南松 ( Pinus yunnanensis)、兰桉 (Eucalyptus globulus)、华山 松 (Pinus armandi)等, 以减少和避免紫茎泽兰的侵 占, 最终实现植物替代( 何大愚和梁家社, 1988; 向业 勋, 1991; 孙劲, 2003)。贵州等省区利用优质牧草皇 竹草 ( Pennisetumsinese) 来抑制紫茎泽兰种子的传 
播蔓延, 是一种很有潜力的替代控制种 (孙劲, 2003)。

\section{2 紫茎泽兰的化学防除}

虽然化学防治不能根除紫茎泽兰, 但对危害严 重、面积大, 在人工清除有困难的地方适当采用化学 药剂进行防治, 结合人工清除, 在一定范围内是可行 的。在使用时, 要远离水源和人群, 保护环境与生物 安全。

澳大利亚的 Auld 就进行了一系列紫茎泽兰化 学防除的研究。Auld (1972)根据除草剂的有效性、 专一性及成本 3 个方面的综合考虑, 筛选出 3 种化 学除草剂: 1) 2, 4-D 胺; 2) 2, 4-D 和 2, 4, 5-T 的混合 物; 3 ) 氯酸钠。并通过研究发现: $0.6 \%$ 的 2, 4-D 胺 在秋季施用具有很好的专一性, 并且可以使紫茎泽 兰达到很高的死亡率。

在我国, 向业勋 (1991) 等提出在紫茎泽兰的营 养生长期, 可以利用草甘膦水剂加洗衣粉, 或用 2,4$\mathrm{D}$ 加敌草隆进行叶面喷雾来防除。在云南省双柏县 利用 2,4-D 进行紫茎泽兰化学防除的试验, 效果良 好(刘伦辉等, 1985)。在四川省, 利用 2, 4-D 丁酯、 草甘膦、盖灌能等对紫茎泽兰进行防治试验, 也取得 了较好的效果。此外,敌草隆、毒草胺、2, 4- D 异丁 酯、毒树剂等对紫茎泽兰均有一定的防治效果(唐) 江和周俗, 2003)。

\section{3 紫茎泽兰的生物防除}

生物防除是控制外来种最有前景的途径, 其主 要方法包括用真菌和昆虫来控制外来种。Bess 和 Haramoto (1959) 将泽兰实蝇 (Procecidochares utilǐs) 从 墨西哥引入夏威夷, 对紫茎泽兰进行生物防治。研 究发现, 泽兰实蝇可以严重抑制紫茎泽兰的生长, 主 要是通过在其植株上产生虫瘞, 使其开花数量减少, 甚至导致死亡; 我国学者对于泽兰实蝇也开展了广 泛的研究 (何大愚和梁家社, 1988; 张智英等, 1988; 陈旭东和何大愚, 1990a, 1990b), 获得了相似的结论 (刘文耀等, 1991)。提出了最佳释放虫量指标为每 条虫占有 10 个枝条 (陈旭东和何大愚, 1990b), 并从 多方面探讨了泽兰实蝇对于紫茎泽兰的影响 (郑征 等, 1989; 陈旭东和何大愚, 1990a; 代聪等, 1991), 发 现泽兰实蝇可以减弱紫茎泽兰的光合作用; 影响紫 茎泽兰的密度、种子的入侵能力以及种子的萌发率; 而且, 由于泽兰实蝇的寄生使营养流集中转向茎部, 一部分形成膨大的虫瘞, 累积了大量的生物量, 另一 部分提供给泽兰实蝇进行发育, 致使根系发育不良, 根冠比减小, 影响根系的矿质营养及水分的吸收, 严
重影响紫茎泽兰的生长发育。但是就野外观察发 现, 这种天敌对于控制紫茎泽兰的效果并不理想 (刘 伦辉等, 1985)。

在国外, 有研究者将食花虫 (Dihammus argentatus ) 与泽兰实蝇和一种真菌结合起来控制紫茎泽兰, 也只是抑制了其扩散速度 (Auld, 1969a; Auld \& Martin, 1975)。

泽兰尾孢菌 (Cercospora eupatorii) 在澳大利亚的 昆士兰首次被发现, 它能够引起紫茎泽兰的叶斑病, 使植株生长受阻 (Auld, 1969a)。在中国, 于 1982 年 被首次报道 (刘锡琎和郭英兰, 1982), 郭光远等 $(1991,1992)$ 对于该菌的致病特征和病原菌的形态 特征等进行了详细的研究。杨宇容和郭光远 (1991) 发现该菌可以使紫茎泽兰的株高、叶片数和花朵数 等明显降低。

链格狍菌 ( Alternaria alternata) 菌株的菌丝体侵 染紫茎泽兰的速度快、致病力强, 能快速杀死该植 物, 被认为是控制紫茎泽兰很有潜力的新途径( 强 胜, 1998)。万佐奎等(2001)就链格孢菌毒素对紫茎 泽兰的致病机理进行了深入研究, 结果发现, 链格孢 菌毒素使紫茎泽兰叶组织细胞膜透性上升, $\mathrm{Na}^{+}$和 $\mathrm{K}^{+}$渗漏量增加, 膜脂过氧化加强, 丙二醛含量上升, 说明致病毒素能够引起细胞膜伤害, 造成膜功能的 紊乱。链格孢菌毒素处理的紫茎泽兰叶片中过氧化 物酶、抗坏血酸过氧化物和过氧化氢酶的活性均较 对照降低, 可能使活性氧清除系统中酶系统遭到破 坏, 活性氧过量积累, 细胞因此受到伤害, 最终使紫 茎泽兰叶片表现出受害症状。但是致病毒素在细胞 膜上的受体以及信导的传递等有待进一步研究。另 外, 链格孢菌是微生物除草剂开发中极其重要的一 类真菌, 有可能成为生物源的化学除草剂。

\section{4 研究展望}

\section{1 紫茎泽兰长距离传播模型研究}

种子是紫茎泽兰扩散的主要途径, 种子长距离 漂移是决定外来物种大范围扩散的关键因素, 近年 来, 种子长距离迁移已引起了许多研究人员的重视 (Cain et al., 2000; Nathan et al., 2002; 郑景明等, 2004 )。如果能够运用反应-扩散模型、复合种群模 型等来对紫茎泽兰的扩散进行预测, 必将有助于外 来植物扩散的预测体系的发展。

\section{2 紫茎泽兰化感作用}

紫茎泽兰的化感作用在其入侵成功的过程中扮 演着重要角色, 但是还是缺乏在原产地与入侵地化 
感作用的对比研究, 而这项研究应该有助于我们理 解其入侵机制, 了解其在原产地不能大面积扩散的 原因。另外, 对于赋予其具有化感作用的化学物质 的结构、性质及作用机制尚需进一步研究。

\section{3 紫茎泽兰生理生态适应性研究}

紫茎泽兰作为一种恶性杂草, 其生理生态研究 还是了解的很少, 特别是通过控制实验来开展对紫 茎泽兰扩散过程的限制因子的研究和在不同水热条 件和光照条件下的生理适应机制, 以及它对这些限 制因子的耐受范围的研究。所以, 对于紫茎泽兰开 展对模拟不同气候条件(包括平均温度、极端温度、 大气湿度、光照强度等)下植物生理生态响应的研 究, 了解其在不同气候条件下的生理适应机制, 将使 我们能够洞悉外来入侵种在新入侵地的生态环境下 的扩散机制, 预测其潜在的入侵区域, 发现其适应过 程中的薄弱环节。

\section{4 紫茎泽兰传粉过程及其生殖生态学特性}

紫茎泽兰传粉过程及其生殖生态学的一些特性 目前仍没有进行较系统的研究, 而外来植物的繁殖 能力大小对入侵是否成功意义很大, 繁殖能力与植 物的入侵能力呈正相关 (Barret, 1983)。紫茎泽兰无 融合生殖的基因调控机制, 以及原产地和新入侵地 的繁育系统的变化, 都是将来研究的热点。

紫茎泽兰是一种无融合生殖的三倍体 (Baker, 1965; Auld, 1970; Tendani \& Steven, 2004), 而且其遗 传多样性较高 (强胜, 2004), 推测其原因可能有两 点: 1) 紫茎泽兰在中国的入侵不是单次传入, 而是多 次传入;2)紫茎泽兰可能并不是专性无融合生殖, 还 具有兼性有性生殖。这方面的工作应结合分子生物 学和细胞生物学的手段来对紫茎泽兰的繁育系统进 行更加深入的研究, 从而加深对紫茎泽兰繁殖特性 的理解。

\section{5 紫茎泽兰生物防除}

经过多年实践证明, 目前在中国仍缺乏对控制 紫茎泽兰危害行之有效的方法。人工防除只能挖除 一部分农田、果园的紫茎泽兰, 且费时费力; 化学药 剂防治不可避免地会对环境产生危害; 生物防治是 控制紫茎泽兰最有前景的方法, 但目前几种生物防 治的方法都不能有效控制紫茎泽兰。开发新的除草 剂品种, 包括利用基因和细胞融合技术重组来研究 新的除草剂( Tureon \& Yoder, 1985), 以及直接利用可 以杀死土壤中杂草种子的微生物来研制新的生物除 草剂品种 (孙劲, 2003), 是非常有前景的。

\section{参 考 文 献}

Angiras NN, Singh SD, Singh CM (1988). Allelopathic effects of weeds on germination and seeding growth of maize and soybean. Indian Journal of Weed Science, 20, $82-87$.

Angiras NN, Singh SD, Singh CM (1989). Allelopathic effects of some weeds on germination and growth of chickpea (Cicer ariet). Indian Journal of Weed Science, 21, 85-87.

Arunachalam K, Arunachalam A, Melkania NP (1999). Influence of soil properties on microbial populations, activity and biomass in humid subtropical mountainous ecosystems of India. Biology and Fertility of Soils, 30, $217-223$.

Auld BA (1969a). Incidence of damage caused by organisms which attack crofton weed in the Richmond-Tweed region of New South Wales. Australian Journal of Science, 32, 163.

Auld BA (1969b). The distribution of Eupatorium adenophorum Spreng. on the far north coast of New South Wales. Journal and Proceedings of the Royal Society of New South Wales, 102,159161 .

Auld BA (1970). Eupatorium weed species in Australia. Pans, 16 (1), $82-86$.

Auld BA (1971). Survey of weed problems on the north coast of New South Wales. Tropical Grasslands, 5, 27 - 30 .

Auld BA (1972). Chemical control of Eupatorium adenophorum, crofton weed. Tropical Grasslands, 6, 55-60.

Auld BA, Martin PM ( 1975 ). The auteclogy of Eupatorium adenophorum Spreng. in Australia. Weed Research, 15, 27 31 .

Baker HG (1965). The modes of origin of weeds. In: Baker HG, Stebbins GL eds. The Genetics of Colonizing Species. Academic Press, New York, 147 - 168.

Barret SCH (1983). Crop mimicry in weeds. Economic Botany, $37,255-282$.

Baruah NC, Sarma JC, Sarma S, Sharma RP (1994). Seed germination and growth inhibitory cadinenes from Eupatorium adenophorum Spreng. Journal of Chemical Ecology, 20, 1885 1892.

Bazzaz FA (1986) . Life history of colonizing plants: some demographic, genetic, and physiological features. In: Mooney HA, Drake JA eds. Ecolology of Biological Invasions of North America and Hawaii. Springer-Verlag, New York, 96-108.

Bess HA, Haramoto FH (1959). Biological control of Pamakani Eupatorium adenophorum in Hawii by a Tephritid gall fly, Procecidochares utilis. II . Population studies of the weed, the fly and the parasites of the fly. Ecology, 40, 244-249.

Bohlmann F, Rajindex, KG (1981). Six cadinene derivatives from Ageratina adenophora. Phytochemistry, 20,1432-1433.

Bordoloi MJ, Shakla VD, Sharma RP (1985). Absolute stereochemistry of the insect antifeedant cadinene from Eupatorium adenophorum. Tetrahedron Letter, 26,509-510.

Cain ML, Milligan BG, Strand AE (2000). Long-distance seed dispersal in plant populations. American Journal of Botany, 87, 


\section{$1217-1227$}

Callaway RM, Aschehoud ET (2000). Invasive plants versus their new and old neighbors: a mechanism for exotic invasion. Science, $290,521-523$.

Chen KJ(陈开基) (1989). The potential threat of vicious weed $E$ upatorium adenophorum Spreng. Plant Quarantine (植物检疫), 3,192 - 193. (in Chinese)

Chen XD(陈旭东), He DY (何大愚) (1990a). Study on control effect of Procecidochares utilis on Eupatorium adenophorum and its evaluation. Journal of Weed Science (杂草学报), 4(3), 1-

6. (in Chinese with English abstract)

Chen XD(陈旭东), He DY (何大愚) (1990b). Study on the strategy of biological control of Eupatorium adenophorum by using Procecidochares utilis. Chinese Journal of Applied Ecology (应用 生态学报), 1, 315-321. (in Chinese with English abstract)

Cook CDK (1985). Range extension of aquatic vascular plant species. Journal of Aquatic Plant Management, 23, 1 - 6 .

Dai C(代聪), Wei Y (魏艺), He DY (何大愚) (1991). A study on effect of Procecidochares utilis on control of Eupatorium adenophorum. Journal of Weed Science (杂草学报), 5(1),2429. (in Chinese with English abstract)

Ding ZH (丁智慧), Guo YB (郭玉涁), Ding JK (丁靖垲) (1999). Chemical constituents from the flowers of Eupatorium adenophorum. Acta Botanica Yunnanica (云南植物研究)，21, 505 - 511. (in Chinese with English abstract)

Dodd AP (1961) . Biological control of Eupatorium adenophorum in Queensland. Australian Journal of Science, 23, 356-365.

Duan H (段慧) (2003) . Eupatorium adenophorum Spreng. Chinese Journal of Weed Science (杂草科学) , (2), 36-38. (in Chinese)

Guo GY (郭光远), Ma J (马俊), Yang YR(杨宇容), Liu Y (刘 勇), Xu LH(徐丽华), Jiang CL (姜成林) (1991). New leafspot disease of Eupatorium adenophorum, caused by Mycovellosiella eupatorii-odorati in China. Acta Phytopathologica Sinica (植物病理学报), 21, 245-250. (in Chinese with English abstract)

Guo GY(郭光远), Yang YR(杨宇容), Ma J(马俊), Liu Y (刘 勇), Xu LH(徐丽华), Jiang CL(姜成林) (1992). Studies on the biological characteristics of Mycovellosiella eupatorii-odorati (Yen) Yen, a potential pathogen for the biological control of crofton weed, Eupatorium adenophorum. Chinese Journal of Biological Control(生物防治通报),8,120-124. (in Chinese with English abstract)

He AJ(和爱军), Liu LH(刘伦辉) (1990). Effect of water extract of Eupatorium adenophorum on the germination of several plants. Chinese Journal of Weed Science (杂草科学), (4), 35 - 38. (in Chinese)

He DY(何大愚), Liang JS(梁家社) (1988). Advances in the control research of Eupatorium adenophorum. Advances in Ecolo$g y$ (生态学进展 $), 5,163$ - 168. (in Chinese with English abstract)
Hobbs R, Humphries S (1995). An integrated approach to the ecology and management of plant invasions. Conservation Biology, 9, $761-770$.

Li RT(李蓉涛), Ding ZH(丁智慧), Ding JK(丁靖垲) (1997). Chemical constituents from Eupatorium adenophorum. Acta Botanica Yunnanica (云南植物研究), 21, 505-511. (in Chinese with English abstract)

Li ZY (李振宇), Xie Y (谢炎) (2002). Invasive Alien Species in China (中国外来入侵种). China Forestry Publishing House, Beijing, 163. (in Chinese)

Liu LH (刘伦辉), Xie SC (谢寿昌), Zhang JH (张建华) (1985). Studies on the distribution, harmfulness and control of Eupatorium adenophorum Spreng. Acta Ecologica Sinica (生态学 报),5,1-6. (in Chinese with English abstract)

Liu LH(刘伦辉), Liu WY (刘文耀), Zheng Z(郑征), Jing GF (荆桂芬) (1989). The characteristic research of autecology ecology of Pamakani (Eupatorium adenophorum). Acta Ecological Sinica (生态学报), 9, 66 - 70. (in Chinese with English abstract)

Liu WY(刘文耀), Liu LH(刘伦辉), He AJ(和爱军) (1991). The effect of Procecidochares utilison growth and development, distribution of biomass of Eupatorium adenophorum. Acta Ecologica Sinica (生态学报), 3, 291 - 293. (in Chinese with English abstract)

Liu WY(刘文耀), Liu LH(刘伦辉), Zheng Z(郑征) (1988). Photosynthetic characteristics of Eupatorium adenophorum and their ecological significance. Acta Botanica Yunnanica (云南植 物研究) , 10,175-181. (in Chinese with English abstract)

Liu XJ(刘锡进), Guo YL (郭英兰) (1982). Studies on some species of the genus Phaeoramularia in China. Acta Phytopathologica Sinica (植物病理学报), 12(4), 1-15. (in Chinese English abstract)

Lu ZJ(卢志军), Ma KP (马克平) (2004). The influence of topographical factors on the invasion of the alien species, Eupatorium adenophorum. Acta Phytoecologica Sinica (植物生态学报),28, 761 - 767. (in Chinese with English abstract)

Nathan R, Katul GG, Horn HS, Thomas SM, Oren R, Avissar R, Pacala SW, Levin SA (2002). Mechanisms of long-distance dispersal of weed by wind. Nature, 377,616-618.

Newsome AE, Noble IR (1986) . Ecological and physiological characteristics of invading species. In: Groves RH, Burdon JJ eds. Ecology of Biological Invasions: an Australian Perspective. Australian Academy of Sciences, Canberra, $1-20$.

Noble I (1989) Attributes of invaders and invading process: terrestrial and vascular plants. In: Drake J, Mooney HA, Dicastri F, Groves RH, Kruger FJ, Rejmanek M, Willamson M eds. Biological Invasions: a Global Perspective. John Wiley and Sons, New York, $301-313$.

Papes M, Peterson AT (2003). Predicting the potential invasive distribution for Eupatorium adenophorum Spreng. Journal of Wuhan Botanical Research (武汉植物学研究), 21, 137 - 
142.

Qiang S (强胜) (1998). The history and status of the study on crofton weed (Eupatorium adenophorum Spreng. ) a worst worldwide weed. Journal of Wuhan Botanical Research (武汉植物学 研究) , 16, 366-372. (in Chinese)

Qiang S(强胜) (2004). Genetic diversity in populations of Eupatorium adenophorum detected by AFLP marker. Journal of Nanjing Agricultural University (南京农业大学学报),27, 64. (in Chinese)

Rejmánek M, Richardson DM (1996). What attributes make some plant species more invasive? Ecology, 77, 1655 - 1661 .

Shen YX(沈有信), Liu WY(刘文耀) (2004). Persistent soil seed bank of Eupatorium adenophorum. Acta Phytoecologica Sinica (植物生态学报), 28,768-772. (in Chinese with English abstract)

Song QS(宋启示), Fu Y (付昀), Tang JW(唐建维), Feng ZL (冯志立), Yang CR (杨崇仁) (2000). Allelopathic potential of Eupatorium adenophorum. Acta Phytoecologica Sinica (植物生 态学报),24, 362 - 365. (in Chinese with English abstract)

Sun J (孙劲) (2003). Control of Eupatorium adenophorum, an overview. Yunnan Journal of Animal Science and Veterinary Medicine (云南畜牧兽医),4,11-13.(in Chinese)

Tang CJ (唐川江), Zhou S (周俗) (2003). Introduction to the controlling and utilizing of Eupatorium adenophorum Spreng. Journal of Sichuan Grassland(四川草原) ,6, 7-10. (in Chinese with English abstract)

Tendani DR, Steven DJ (2004). Breeding systems of invasive alien plants in South Africa: does Baker's rule apply? Diversity and Distributions, 10, $409-416$.

Thompson K, Grime JP (1979). Seasonal variation in the seed banks of herbaceous species in ten contrasting habitats. Journal of Ecology, 67,893-921.

Thompson K (2000) . The fuctional ecology of soil seed banks. In: Fenner M ed. Seeds: the Ecology of Regeneration in Plant Communities 2nd edn. CAB International, UK, 215 - 235.

Tripathi RS, Singh RS, Rai JPN (1981). Allelopathic potential of Eupatorium adenophorum, a dominant ruderal weed of Meghalaya. Proceedings of Indian Academy of Sciences, 47, 458 - 465.

Tureon G, Yoder OG (1985). Genetrically engineered fungi for weed control. Applications and Research, $221-230$.

Wan ZX(万佐胥), Zhu JJ (朱晶晶), Qiang S (强胜) (2001). The pathogenic mechanism of toxin of Alternaria alternata (Fr.) Keissler to Eupatorium adenophorum Spreng. Journal of Plant Resources and Environment (植物资源与环境学报),10(3)，47

- 50. (in Chinese with English abstract)

Wang, JF(王俊峰), Feng YL(冯玉龙) (2004). The effect of light intensity on biomass allocation, leaf morphology and relative growth rate of two invasive plants. Acta Phytoecologica Sinica (植
物生态学报),28, 781 - 786 (in Chinese with English abstract) Wang JF(王俊峰), Feng YL (冯玉龙), Liang HZ (梁红柱) (2004). Acclimation of photosynthetic characteristics to growth light intensity in Eupatorium adenophorum Spreng. Chinese Journal of Applied Ecology (应用生态学报), 15, 1373 - 1377. (in Chinese with English abstract)

Xiang YX (向业勋) (1991). The distribution, harmfulness and elimination of Eupatorium adenophorum Spreng. Chinese Journal of Weed Science (杂草科学), (4), 10-11. (in Chinese)

Xu YL (许云龙), Shan XZ (单欣宙), Wang ZY (王宗玉) (1988). The first report on the chemical constituents of Eupatorium adenophorum. Acta Botanica Yunnanica (云南植物研究), 10, 238 - 240. (in Chinese with English abstract)

Yang YR (杨宇容), Guo GY (郭光远) (1991). Study on effect of Mycovellosiella eupatorii-odorati upon growth and physiological parameters of Eupatorium adenophorum. Journal of Weed Science (杂草学报),5(1),6-11. (in Chinese with English abstract) $\mathrm{Yu}$ XJ(于兴军), Yu D(于丹), Ma KP (马克平) (2004). Relationships between allelopathy and invasiveness by Eupatorium adenophorum in different sites. Acta Phytoecologica Sinica (植物 生态学报),28,773-780. (in Chinese with English abstract) Zhang ZY(张智英), Wei Y(魏艺), He DY (何大愚) (1988). Biology of a gall fly, Procecidochares utiľss [Dip. : Tephritidae] and its impact on crofton weed, Eupatorium adenophorum. Chinese Journal of Biological Control(生物防治通报),4, 10-13. (in Chinese with English abstract)

Zhao GJ(赵国晶), Ma YP(马云萍) (1989). The investigation research on the distribution and harmfulness of Eupatorium adenophorum Spreng. in Yunnan Province. Journal of Weed Science (杂草学报),3(2), 37-40. (in Chinese with English abstract)

Zheng JM (郑景明), Sang WG (桑卫国), Ma KP (马克平) (2004). Advances in model construction of anemochoric seed long distance dispersal. Acta Phytoecologica Sinica (植物生态学 报), 28, 414-425. (in Chinese with English abstract)

Zheng Z(郑征), Tang JW (唐继武)，Liu WY (刘文耀)，Chen XD (陈旭东) (1989). Study on effect of Procecidochares utiľs growth and photosynthesis of Eupatorium adenophorum. Journal of Weed Science (杂草学报),3(2), 21 - 24. (in Chinese with English abstract)

Zhou S(周俗), Tang CJ(唐川江), Zhang XY (张新跃) (2004).

The damage situation and control countermeasures for Eupatorium adenophorum in Sichuan Province. Pratacultural Science (草业 科学) , 1, 24-26. (in Chinese with English abstract)

Zhou S(周俗)，Xie YL (谢永良) (1999). The investigation report on the poisonous and injurious plant - Eupatorium adenophorum Spreng. in Sichuan Province. Journal of Sichuan Grassland (四川草原) ,2, 39-42. (in Chinese with English abstract) 